\title{
WSTĘP
}

Grażyna Zarzycka ${ }^{1}$

\section{POLONISTYCZNA LAPSOLOGIA GLOTTODYDAKTYCZNA WCZORAJ I DZISIAJ}

\begin{abstract}
Słowa kluczowe: lapsologia, glottodydaktyka polonistyczna, polonistyczna lapsologia glottodydaktyczna, błąd glottodydaktyczny

Streszczenie. Autorka artykułu proponuje, by mianem polonistycznej lapsologii glottodydaktycznej określić dyscyplinę naukową zajmującą się badaniami nad różnego rodzaju błędami pojawiającymi się w procesie uczenia się - nauczania języka obcego. Błędy glottodydaktyczne, na których koncentruje się ta dyscyplina, mogą być popełniane zarówno przez uczących się, jak i nauczycieli w każdej fazie procesu edukacyjnego. W pierwszej części artykułu autorka przedstawia dzieje polonistycznych badań lapsologicznych, wykorzystując jako materiał źródłowy zawartość poszczególnych tomów czasopisma „Acta Universitatis Lodziensis. Kształcenie Polonistyczne Cudzoziemców", publikowanych w latach 1987-2014 (od tomu 0 do 21). W części II omawia treść najnowszego 22 tomu czasopisma zatytułowanego Błąd glottodydaktyczny, zwracając uwagę na najnowsze trendy w zdefiniowanej wcześniej dyscyplinie.
\end{abstract}

O tym, w jakim kierunku rozwija się dyscyplina, którą określam tu jako polonistyczną lapsologię glottodydaktyczną, można się zorientować, analizując zawartość poszczególnych tomów niniejszego rocznika - pierwszego w Polsce czasopisma naukowego zajmującego się problemami nauczania języka polskiego jako obcego (jpjo) ${ }^{2}$. W czasopiśmie „Acta Universitatis Lodzienis. Kształcenie Polonistyczne Cudzoziemców" (KPC), którego nienumerowany próbny tom został wydany w 1987 roku, a kolejny (z numerem 1) w roku następnym, znajdzie-

\footnotetext{
${ }^{1}$ grazyna.zarzycka@wp.pl; Katedra Lingwistyki Stosowanej i Kulturowej, Wydział Filologiczny, Uniwersytet Łódzki,90-236 Łódź, ul. Pomorska 171/173.

${ }^{2}$ Pełne tomy KPC, również archiwalne (z wyjątkiem tomu próbnego z 1987 r.), zostały zdeponowane w Repozytorium Cyfrowym UŁ pod adresem: http://dspace.uni.lodz.pl:8080/xmlui/handle/11089/1350.
} 
my sporą liczbę artykułów (ok. 9\% wszystkich), których autorzy podejmowali polonistyczne analizy lapsologiczne ${ }^{3}$.

Redaktorzy poszczególnych tomów umieszczali takie prace w działach zatytułowanych: „Zagadnienia nauczania wymowy, gramatyki i słownictwa” (tak w tomie próbnym z 1987 r.; zob. artykuły J. Kucharczyka (1987 a i b), E. Sajenczuk (1987), L. Sikorskiego (1987), a także w sekcjach zatytułowanych „Z badań konfrontatywnych” (tak w tomie 1 z 1988; zob. W. Nowikow 1988 a i b) lub „Prace konfrontatywne” zob. w tomie 7/8 z 1996 r. prace M. Pančikovej (1996), B. Kruckiej (1996), T. Sikorskiej (1996); podobnie w tomie 12 z 2002 r. (zob. Krucka 2002, Kijewska 2002) oraz w tomie 14 z 2005 r. (zob. Magajewska 2005, Krucka 2005). Gdy autorzy zajmowali się w swoich pracach różnicami zachodzącymi w systemach dwóch języków, wtedy taki artykuł umieszczano w dziale „Zagadnienia ogólne” (tak w tomie 9 z 1997 r.; zob. artykuł B. Kruckiej (1997) o odmiennościach w systemie składniowym języka polskiego i rosyjskiego) lub w dziale „Gramatyka” (tak w tomie 10 z 1998 r.; zob. artykuł B. Kruckiej (1998) o przeciwdziałaniu błędom interferencyjnym studentów rosyjskojęzycznych).

$\mathrm{W}$ nowszych tomach podejście konfrontatywne jest nadal obecne, zob. np. tom 18 KPC z 2011 r., w którym w dziale „Teksty a gramatyka” można znaleźć reprezentatywne dla niego artykuły K. Bednarskiej (2011), M. Wtorkowskiej (2011), O. Orhorilko (2011). W tym samym tomie pojawiły się również prace, których autorzy badają błędy w odmienny sposób; zob. zmieszczony w tym samym dziale artykuł M. Stasieczek-Górnej (2011) na temat naruszeń w zakresie szyku zdania w wypowiedziach cudzoziemców różnych narodowości. W tomie tematycznym „Glottodydaktyka polonistyczna a lingwistyka kulturowa” (tom 19 z 2012 r.) A. Krawczuk (2012) zaproponowała kognitywne podejście do błędów popełnianych przez Ukraińców uczących się języka polskiego jako obcego, wskazując na „różnice dotyczące realizacji kategorii gramatycznych w języku polskim i ukraińskim", J. Kowalewski (2012) powiązał z kolei błędy składniowe popełniane przez uczących się jpjo na Ukrainie z kategorią językowego obrazu świata.

W tomie 20 KPC Glottodydaktyka - media - komunikacja. Kształtowanie kompetencji komunikacyjnej z 2013 r. prace, w których zostały podjęte refleksje lapsologiczne, zostały umieszczone w kilku działach tematycznych. Np. w sekcji tematycznej „Kształtowanie kompetencji językowych: gramatyka, fonetyka, leksyka" znajdujemy artykuł K. Nikołajczuk (2013) konfrontujący kompetencję Polaków oraz Ukraińców w zakresie stosowania polskiej frazeologii. W dziale tematycznym „Kształtowanie kompetencji kulturowej. Interferencje kulturowe” możemy znaleźć prace A. Krawczuk (2013), H. Borysiewicz (2013) i M. Skury (2013), w których przeanalizowano błędy mające podłoże kulturowe, pojawiające się $\mathrm{w}$ prasie polskojęzycznej publikowanej na Ukrainie, w trakcie nauki

\footnotetext{
${ }^{3}$ Dyskurs glottodydaktyczny w KPC został omówiony w: Zarzycka (2013).
} 
języka polskiego na Białorusi oraz w wypowiedziach uczących się jpjo w Niemczech. W sekcji ,Język w mediach” zamieszczono artykuł M. Witkowskiej-Gutkowskiej (2013), w którym autorka analizuje usterki językowe, powstałe w wyniku interferencji języka czeskiego, pojawiające się w polskojęzycznej prasie zaolziańskiej; autorka kontynuuje w nim temat jakości polszczyzny osób bilingwalnych urodzonych i mieszkających w Czechach (zob. Witkowska-Gutkowska 2008 i 2011). K. Sitkowska (2013) w artykule z tej samej sekcji tematycznej zaproponowała z kolei analizę polszczyzny cudzoziemców występujących w programach telewizyjnych, koncentrując się na ich kompetencji komunikacyjnej. W dziale „Rozwijanie kompetencji komunikacyjnej w procesie kształcenia językowego" została natomiast umieszczona praca K. Kubackiej (2013) dotycząca korekty nauczycielskiej i jej roli w kształtowaniu wypowiedzi ustnych uczących się jpjo.

W tomie 21 KPC z 2014 r. o tytule Glottodydaktyka-media-komunikacja. Negocjowanie znaczeń autorzy powiązali zagadnienia lapsologiczne z tematami wiodącymi tomu: negocjowaniem znaczeń i komunikacją; np. A. Seretny (2014) i K. Kubacka (2014) podjęły temat strategii negocjacyjnych (nauczycielskich i uczniowskich) pojawiających się w dyskursie interakcyjnym podczas lekcji jpjo. Pracę pierwszej autorki umieszczono w dziale „Zagadnienia ogólne”, a drugiej w sekcji: „Negocjowanie znaczeń a rola nauczyciela”. Artykuły lapsologiczne pojawiły się także w kolejnych kategoriach tematycznych; w dziale „Negocjowanie znaczeń a proces glottodydaktyczny" znalazł się artykuł U. Bieleckiej (2014) o dysleksji na lekcji jpjo, a artykuł A. Karolczuk (2014), którego tematem były działania lektora w sytuacji naruszania normy leksykalnej przez uczących się.jpjo, w sekcji „Negocjowanie znaczeń a gramatyka i leksyka”. Analizując tematykę prac opublikowanych w tym jednym tylko polonistycznym czasopiśmie glottodydaktycznym, można zauważyć, że w pracach opublikowanych w XX wieku najpowszechniej stosowano podejście konfrontatywne (porównawcze), określane też niekiedy jako analiza kontrastywna. Autorzy prac porównywali błędy uczących się w zakresie realizacji określonych zagadnień z zakresu wymowy, gramatyki, leksyki, frazeologii, rzadziej z zakresu pisowni czy słowotwórstwa. Przyczyn błędów doszukiwano się w różnicach między badanymi systemami językowymi. Badacze stosujący podejście konfrontatywne byli zwykle dwujęzycznymi ekspertami w zakresie porównywanych języków. Przedmiotem badań były błędy popełniane przez uczących się języka polskiego w jednorodnych grupach językowych poza Polską (np. na filologiach za granicą w Serbii, Bułgarii, na Ukrainie, Białorusi, Słowacji, we Włoszech, w Niemczech, w Wietnamie, w Niemczech), bądź przez reprezentantów jednej grupy językowej uczących się jpjo w Polsce, np. studentów hiszpańskojęzycznych czy rosyjskojęzycznych. Zastanawiać może fakt, że w pierwszych dwóch dekadach istnienia KPC nie pojawiły się na jego łamach prace zrealizowane $\mathrm{w}$ duchu podejścia określanego jako error analysis, 
popularnego już w latach 80. czy 90. XX wieku. Jak wiemy, przedstawiciele tej glottodydaktycznej szkoły lapsologicznej odeszli od obowiązującej w podejściu konfrontatywnym zasady porównywania dwóch lub więcej systemów językowych z intencją poszukiwania miejsc, w których może dojść do interferencji językowej. Zajęli się natomiast zobrazowanymi w błędach różnych uczących się cechami interjęzyka.

Autorzy analizowanych prac zmieniają optykę w pierwszej dekadzie XXI wieku - w przeanalizowanych tomach tematycznych KPC znajdujemy artykuły wiążące błędy pojawiające się w wypowiedziach uczących się jpjo z ich językowym obrazem świata, zakorzenionymi wzorcami kulturowymi. Autorzy przyglądają się błędom popełnianym w tekstach medialnych, zaczynają stosować perspektywę psycholingwistyczną, pragmatyczną i kulturową. Warto także zwrócić uwagę na to, że błędy analizowane w artykułach opublikowanych w KPC były błędami w y $\nmid$ ą c z n i e u c z n i o w s k i m i. O nauczycielu języka polskiego jako obcego i jego roli jako negocjującego (wraz z uczącymi się) znaczenia badacze piszą dopiero $\mathrm{w}$ pracach opublikowanych $\mathrm{w}$ tomach najnowszych, a więc w drugiej dekadzie XXI wieku.

$* * *$

Niniejszy, 22 tom „Kształcenia Polonistycznego Cudzoziemców”, noszący tytuł Błąd glottodydaktyczny, jest wielogłosową narracją współczesnych glottodydaktyków na temat ich rozumienia błędów popełnianych w trakcie nauki języka obcego, w szczególności jpjo, przez obie strony procesu - ucznia i nauczyciela. „Bohater” tego tomu - błąd glottodydaktyczny - nie jest więc już jedynie błędem uczniowskim. Lapsologia glottodydaktyczna jako dyscyplina badająca różnorodne błędy, które pojawiają się wtedy, gdy przebiega proces nauczania-uczenia się, znacznie rozszerzyła dziś swój zakres, stając się punktem obserwacyjnym procesów błędotwórczych, które mogą zachodzić w fazie przygotowania do lekcji, w czasie lekcji i w fazie oceny (ewaluacji) i dotyczyć obu stron procesu. Zwrócenie uwagi na błędy nauczycielskie jest niewątpliwie związane z wyzwaniami, jakie stwarza prowadzenie specjalizacji i studiów podyplomowych z zakresu nauczania języka polskiego jako obcego i drugiego.

Tom Bład glottodydaktyczny zawiera 23 artykuły oraz 4 recenzje prac glottodydaktycznych (trzech monografii i jednego podręcznika). Prace zostały umieszczone w sześciu sekcjach tematycznych, w których odbija się wiedza współczesnych badaczy na temat błędów popełnianych w procesie glottodydaktycznym, historii tych badań, metod ich badania oraz sposobów ich naprawy. Zgromadzone tu prace świadczą o zmianie, jaka nastąpiła w podejściu do błędów: kilkoro autorów prac zgromadzonych w tomie przedstawia swoje refleksje i badania na temat błędów popełnianych przez nauczycieli lub kandydatów na lektorów 
języka polskiego jako obcego. Wśród prac znajdziemy oczywiście i takie, w których badacze przedstawili wyniki badań nad błędami uczniowskimi, zastosowali jednak przy tym różnorodne perspektywy badawcze. Kilkoro autorów wystąpiło w roli kontynuatorów tradycji lapsologicznych badań konfrontatywnych, innym bliższe jest podejście reprezentowane przez szkołę określaną jako error analysis. Jednych badaczy zainteresowały błędy nauczycielskie czy uczniowskie popełniane w trakcie konkretnych działań glottodydaktycznych, kolejni skupili swoją uwagę na uczniowskich i nauczycielskich realizacjach językowych odnoszących się do określonych sprawności, np. mówienia, pisania, komunikowania się lub podsystemów języka: wymowy, pisowni czy poprawności gramatycznej, bądź na psychologicznym i kulturowym podłożu błędów glottodydaktycznych. Poniżej przedstawiam omówienie zawartości poszczególnych sekcji tematycznych.

Celem artykułu Grażyny Zarzyckiej prezentowanym we „Wstępie” jest przybliżenie osiągnięć polonistycznej lapsologii w czterech ostatnich dekadach, jak też ukazanie - na przykładzie zawartości niniejszego tomu KPC - kierunków ewoluowania dyscypliny określonej mianem polonistycznej lapsologii glottodydaktycznej.

W sekcji „Teorie, klasyfikacje oraz problemy badania i oceny błędów glottodydaktycznych" zebrano 6 prac o charakterze teoretycznym i przeglądowym, choć nie brakuje w nim także sprawozdań z badań własnych. Tak więc, znane lapsolożki: Anna Dąbrowska i Małgorzata Pasieka, udzielają w swojej pracy odpowiedzi na pytanie o istotę błędu językowego, podejmują refleksje na temat normy glottodydaktycznej, omawiają znaczące prace lapsologiczne oraz przedstawiają w formie tabel typologie „błędów cudzoziemskich” tzn. popełnianych przez cudzoziemców uczących się języka polskiego. Należy też zwrócić uwagę na fakt, że autorki przyjęly inne od zdefiniowanego w niniejszym „Wstępie” rozumienie terminu „błąd glottodydaktyczny”. Według autorek jest to błąd uczniowski popełniany w konkretnej fazie procesu uczenia się, gdy w niniejszym tomie promowane jest rozumienie tego terminu uzależnione od tego, kto popełnia błąd; stąd - wyróżnienie błędów uczniowskich i nauczycielskich (metodycznych).

Prace kolejnych autorów: Kamila Szafrańca i Agnieszki Rabiej, zawierają przegląd prac, które - bądź trwale zapisały się w historii światowej i polskiej glottodydaktyki, bądź tych, które lansują nowe kierunki w badaniach lapsologicznych. K. Szafraniec przybliża czytelnikom najważniejsze amerykańskie koncepcje i szkoły badań nad błędami popełnianymi w trakcie nauki języków obcych (behawioryzm, kognitywizm i najmniej znane w Polsce podejście dialogiczne), natomiast A. Rabiej prezentuje podejścia badawcze do poprawy błędów, przedstawia $\mathrm{w}$ formie schematu proces identyfikacji błędów, jak też omawia najważniejsze sposoby reagowania na nie, zgodne ze współczesnym humanistycznym podejściem do błędów. W kolejnym artykule zamieszczonym w tej sekcji Ewa Wojaczek podejmuje refleksje nad udziałem wykładowcy i studentów w eliminowaniu błędów językowych na zajęciach z niemiecko-polskich tłumaczeń ust- 
nych. W jej artykule znajdujemy zarazem wiele konkretnych przykładów korekty uczniowskiej, do której nawoływała też poprzednia autorka. W dwóch ostatnich artykułach $\mathrm{z}$ tej sekcji rozwijane są zagadnienia normatywne (które zresztą były też ważnymi zagadnieniami artykułów A. Dąbrowskiej i M. Pasieki oraz E. Wojaczek). Tak więc, zarówno Beata Grochala, jak i Wiesław Tomasz Stefańczyk, stawiają pytania o to, jaki rodzaj normy językowej: wzorcowa czy użytkowa - są i powinny być - stosowane w glottodydaktyce polonistycznej. Wnioski autorów są oparte na analizie odstępstw od normy wzorcowej pojawiających się w przykładach użycia znalezionych w podręcznikach akademickich, gramatykach języka polskiego, podręcznikach do nauczania jpjo, w słownikach i gramatykach pedagogicznych. Gdy pierwsza autorka przyjrzała się znalezionym w podręcznikach do nauki jpjo różnorodnym odstępstwom od normy wzorcowej, W. T. Stefańczyk zajął się bardziej szczegółowo zagadnieniem ekspansji męskożywotnej końcówki $-a$ w bierniku liczby pojedynczej w grupie rzeczowników nieżywotnych. Podejście obojga autorów do stosowania w glottodydaktyce normy użytkowej można określić jako przyzwalające - nierestrykcyjne, choć oboje nawołują oczywiście do głębszego przyjrzenia się problemowi.

W sekcji „Psycholingwistyczne i kulturowe spojrzenia na błędy popełniane w trakcie nauki języków obcych" prezentowane są teksty trzech autorek. Natalia Tsai, pracująca na co dzień ze studentami w Tajpej, w anglojęzycznym artykule zajmuje się tematem postrzegania własnych błędow przez Tajwańczyków uczących się języka angielskiego, natomiast Barbara Morcinek-Abramczyk, wykorzystując swoje obserwacje związane z mową ciała, zebrane podczas pracy z Japończykami i Chińczykami, stara się zapełnić lukę w badaniach glottodydaktycznych, jaką jej zdaniem - stanowi nauczanie komunikacji niewerbalnej. Analiza błędow uczących się jpjo, których podłożem są zakłócenia w komunikacji interkulturowej, jaką proponuje Elżbieta Łątka-Likh, to kolejna praca świadcząca o znacznym poszerzeniu zakresu glottodydaktycznych badań lapsologicznych, nawet jeśli są to badania ukierunkowane nadal na błędy uczniowskie.

W sekcji zatytułowanej „Glottodydaktyczne błędy metodyczne” przedstawiane są 4 artykuły poświęcone błędom nauczycielskim. W pierwszej pracy Iwona Janowska przygląda się, odnosząc się do schematu działań nauczyciela przedstawionego w Europejskim Portfolio dla studentów, błędom metodycznym pojawiającym się fazie planowania i prowadzenia lekcji. Proponuje wiele środków zaradczych oraz w części końcowej - jako remedium na błędy - ciągłą refleksję nauczycieli nad własnymi niedociągnięciami połączoną z samokształceniem. Ewa Komorowska w artykule na temat błędów nauczycieli na kursach jpjo w biznesie zwraca uwagę na niedociągnięcia metodyczne m.in. w zakresie doboru materiałów dydaktycznych i metod oraz analizy potrzeb uczących się. We wnioskach autorka postuluje zwracanie większej uwagi przez badaczy na kursy prowadzone poza uczelniami, które bardzo często są ukierunkowane na nauczanie języków 
specjalistycznych. Artykuł Anny Seretny i Ewy Lipińskiej to z kolei dogłębne studium problemu sprawdzania wyników uczących się w tzw. testach osiągnięć (testach nauczycielskich). Autorki rozważają zagadnienie pod kątem ich trafności i rzetelności. Pojęcia te są w ich pracy zdefiniowane, a sposoby zapewnienia testom trafności i rzetelności przedstawione w tabeli. Błędy nauczycielskie związane z makrostrukturą i mikrostrukturą testów ukazane zostały w licznych tabelach i na przykładach zaczerpniętych z prac glottodydaktycznych i obserwacji autorek. Jest to pierwsza znana mi polonistyczna praca glottodydaktyczna tak szczegółowo omawiająca problem jakości testów osiągnięć. Magdalena Wojenka-Karasek i Kamila Kubacka w końcowym artykule tej sekcji przyglądają się natomiast, wykorzystując analizę konwersacji 13 nagrań, zakłóceniom na lekcji jpjo mającym podłoże w niedoskonałościach wypowiedzi lektorów. Wyodrębnione w artykule usterki w zakresie systemu językowego oraz procesu komunikowania powinny skłonić uczących się do autorefleksji, która w przyszłości może zapobiec nieporozumieniom na lekcji jpjo. Artykuł ten pokazuje także, że analiza konwersacji jest metodą, która zapewnia wgląd w materię, logikę i dynamikę wymian komunikacyjnych. Być może więc każdy lektor co najmniej raz do roku powinien rejestrować lekcje, które sam prowadzi, by później poddawać je analizom.

W sekcji tematycznej „Problemy kształcenia zawodowego kandydatów na nauczycieli języka polskiego jako obcego" znajdujemy 2 artykuły, w których autorzy podjęli temat kompetencji językowych przyszłych lektorów - uczestników specjalizacji „Nauczanie Języka Polskiego jako Obcego” Uniwersytetu Łódzkiego. Iwona Dembowska-Wosik omawia błędy językowe w ich pracach pisemnych, a Paula Góralczyk-Mowczan i Mateusz Gaze skupiają uwagę na błędach, które pojawiły się w zadaniu polegającym na adaptacji tekstów literackich. Autorzy odnotowują w obu przypadkach liczne i niepokojące błędy, które - jeśli nie deprecjonują jeszcze przyszłych kandydatów na lektorów jpjo - to zachęcają, zarówno metodyków prowadzących kursy specjalizacyjne, jak i samych kandydatów, do podjęcia działań naprawczych zwiększających ich kompetencje językowe.

Sekcja „Glottodydaktycze błędy uczniowskie. Studia, analizy, rezultaty badań konfrontatywnych" gromadzi 6 prac, w których poszczególni autorzy, zgodnie z własnymi zainteresowaniami naukowymi, kompetencjami językowymi i doświadczeniem zawodowym, analizują błędy uczących się jpjo i Polaków uczących się innego języka słowiańskiego. W trzech pierwszych pracach autorki przedstawiają wyniki szerzej zakrojonych badań nad wymową, pisownią i składnią cudzoziemców uczących się jpjo. Autorką pierwszej pracy jest Michalina Biernacka, która omawia - na podstawie ankiet wypełnionych przez 56 nauczycieli - trudności w nauczaniu cudzoziemców wymowy polskiej oraz przedstawia ich opinie na temat najbardziej skutecznych technik przeciwdziałania błędom wymowy; wyniki badań zostały ukazane w tabelach. Artykuł Joanny Zawadki dotyczy ważnego, o czym szybko przekonuje się każdy lektor, choć z pewno- 
ścią dotąd niedocenianego przez badaczy, problemu trudności, oraz ich przyczyn, w opanowaniu polskiej grafii. Autorka w przedstawianej pracy analizuje sposoby zapisu polskich liter w pracach studentów koreańskich, hiszpańskich i niemieckich, wybierając przykłady konkretnych realizacji z samodzielnie zebranego korpusu tekstów napisanych pismem odręcznym cudzoziemców. Wyróżnia trudności związane z polską grafią wspólne dla wszystkich grup uczących się, jak też specyficzne dla konkretnych grup uczących się. Edyta Wojtczak w pracy na temat kompetencji składniowej i jej niedostatków w polszczyźnie mówionej cudzoziemców uczących się jpjo wyróżniła błędy syntaktyczne w zakresie: składni zgody i rządu, realizacji orzeczenia słowno-imiennego, syntaktyki zdań złożonych i szyku, omówiła także przykłady konstrukcji dysmorficznych. Ukazanie trudności w zakresie realizacji schematów składniowych ma z pewnością duży walor praktyczny, pomaga bowiem zaplanować ćwiczenia utrwalające.

Kolejni autorzy stosują w swoich analizach podejście konfrontatywne, zajmując się interferencją językową pojawiającą się w trakcie nauki jpjo przez innych Słowian: Ukraińców, Białorusinów i Słoweńców, lub innego języka słowiańskiego przez Polaków. Katarzyna Bednarska (słowenistka) omawia błędy interferencyjne w wypowiedziach pisemnych Słoweńców uczących się jpjo spowodowane wpływem innego języka obcego, a Sanja Miletić, native-speakerka zatrudniona jako wykładowczyni w UŁ, zajęła się tematem interferencji językowej w tworzeniu konstrukcji warunkowych przez studentów polskich uczących się języka serbskiego jako obcego. Białorutenista i polonista Radosław Kaleta podejmuje w swojej pracy problem glottodydaktycznych błędów analogicznych na przykładzie języka polskiego i języka białoruskiego, a Jerzy Kowalewski przedstawia szczegółową klasyfikację błędów popełnianych przez uczących się jpjo na Ukrainie. Agnieszka Górska również omawia w swojej pracy sposoby zapobiegania błędów oraz ich eliminacji w grupach uczących sięjpjo z Ukrainy. Wartość zebranych tu prac porównawczych polega na tym, że zostały napisane w większości przez dwujęzycznych badaczy, mających ponadto bezpośrednie doświadczenia z pracy lektorskiej, podczas której opracowali duże korpusy przykładów użycia danego języka. Obserwacje poczynione przez autorów przyczynią się z pewnością do udoskonalenia procesu nauczania języków wśród Słowian uczących się kolejnego języka słowiańskiego, jak też programów kształcenia lektorów.

Tom kończą recenzje. Radosław Kaleta przedstawia opinię na temat pracy Anny Dąbrowskiej, Urszuli Dobesz i Małgorzaty Pasieki: Co warto wiedzieć. Poradnik metodyczny dla nauczycieli języka polskiego jako obcego na Wschodzie, Edyta Pałuszyńska omawia monografię Anny Trębskiej-Kerntopf: Aforyzm w nauczaniu języka polskiego jako obcego, Grażyna Zarzycka recenzuje książkę Radosława Kalety: Polsko-białoruska lapsologia glottodydaktyczna, a Iwona Dembowska-Wosik serię materiałów do nauki języka polskiego jako obcego na poziomie A1 autorstwa Ewy Piotrowskiej-Roli i Marzeny Porębskiej: Polski 
jest cool. Wśród zrecenzowanych prac do zagadnień błędologicznych odnosi się wprost przede wszystkim monografia R. Kalety; komentarze na temat miejsc trudnych w nauczaniu polszczyzny na Wschodzie znajdujemy także w poradniku metodycznym trzech autorek.

Redaktorka niniejszego tomu ma nadzieję, że czytelnicy potraktują zbiór niniejszych prac jako obraz współczesnych trendów, które zarysowały się w ostatnich latach w glottodydaktycznych badaniach lapsologicznych, a w szczególności w badaniach polonistycznych. Polonistyczna glottodydaktyka lapsologiczna to ciągle dyscyplina rozwijająca się; odczuwalny jest przede wszystkim brak słowników błędów uczniowskich, opracowanych dla języków „większych”, „częściej używanych" i poradników dla uczących się i lektorów ${ }^{4}$. Jeśli po zapoznaniu się z zawartością tomu, czytelnicy ujrzą tę dyscyplinę „na nowo" i zechcą przyjrzeć się błędom uczniowskim i nauczycielskim, przyjmując jedną z oferowanych tu perspektyw, cel prac podjętych przez autorów i redaktorkę tomu zostanie spełniony.

\section{BIBLIOGRAFIA}

Alexander L. G. (1996), Right Word. Wrong Word. Words and structures confused and missused by learners of English, Longman Group, GB.

Bartman M., Walton R. ( 2002), Correction. A Positive Approach to Language Mistakes, Thomson, Heinle, Boston, USA.

Bednarska K. (2011), Błędy interferencyjne w pracach pisemnych Słoweńców uczących się języka polskiego jako obcego, ,Acta Universitatis Lodziensis. Kształcenie Polonistyczne Cudzoziemców" nr 18, s. 237-242. http://repozytorium.uni.lodz.pl:8080/xmlui/handle/11089/9381

Bielecka A (2014), Dysleksja na lekcji języka polskiego jako obcego, „Acta Universitatis Lodziensis. Kształcenie Polonistyczne Cudzoziemców” nr 21, s. 85-98. http://repozytorium.uni.lodz. pl:8080/xmlui/handle/11089/8753

Borysiewicz H. (2013), Nauczyć prośby: zagadnienia interferencji językowo-kulturowej w nauczaniu języka polskiego jako obcego $w$ środowisku rosyjskojęzycznym, Acta Universitatis Lodziensis. Kształcenie Polonistyczne Cudzoziemców" nr 20, s. 159-166. http://dspace.uni.lodz. pl:8080/xmlui/handle/11089/4482

Edge J. (1984), Mistakes and Correction, Longman Group, UK.

Hartopp R. (2014), Typical Errors in English. An essential guide to getting the language right, Kraków.

Karolczuk A. (2014), Kłopot ze znaczeniem. Naruszenia normy leksykalnej a działania lektora języka polskiego jako obcego, „Acta Universitatis Lodziensis. Kształcenie Polonistyczne Cudzoziemców" nr 21, s. 203-210. http://repozytorium.uni.lodz.pl:8080/xmlui/handle/11089/8761

Kijewska A. (2002), Bułgarskie błędy ortograficzne w języku polskim i ich podłoże, „Acta Universitatis Lodziensis. Kształcenie Polonistyczne Cudzoziemców” nr 12, s. 69-80. http://repozytorium.uni.lodz.pl:8080/xmlui/handle/11089/12741

\footnotetext{
${ }^{4}$ Wzorcami mogą być glottodydaktyczne słowniki lapsologiczne opracowane dla języka angielskiego (zob. np. Norrish (1983), Alexander (1994), Turton, Heaton (1996) i poradniki metodyczne (zob. np. Edge 1994), Bartram, Walton (2002), czy wydana niedawno w Polsce przez krakowskie wydawnictwo Tertium książka anglisty nauczającego w naszym kraju (zob. Hartopp 2014).
} 
Kucharczyk J. (1987 a), Najczęstsze błędy fleksyjne i sktadniowe w procesie przyswajania języka polskiego przez studentów latynoskich, „Acta Universitatis Lodziensis. Kształcenie Polonistyczne Cudzoziemców" (nr 0 - próbny), s. 89-98 (brak adresu elektronicznego).

Kucharczyk J. (1987 b), Uwagi o trudnościach fonetycznych studentów latynoskich w procesie przyswajania języka polskiego, „Acta Universitatis Lodziensis. Kształcenie Polonistyczne Cudzoziemców" (nr 0 - próbny), s. 82-88 (brak adresu elektronicznego).

Kowalewski J. (2012), Językowy obraz świata zamknięty w składni? Hipotezy na podstawie badań błędów popetnianych w pracach pisemnych przez uczacych się języka polskiego na Ukrainie, „Acta Universitatis Lodziensis. Kształcenie Polonistyczne Cudzoziemców” nr 19, s. 83-92. http://dspace.uni.lodz.pl:8080/xmlui/handle/11089/8923

Krawczuk A. (2012), O kognitywnych uwarunkowaniach wspótczesnej glottodydaktyki: kategorie gramatyczne w nauczaniu Ukraińców języka polskiego, „Acta Universitatis Lodziensis. Kształcenie Polonistyczne Cudzoziemców" nr 19, s. 69-82. http://dspace.uni.lodz.pl:8080/ xmlui/handle/11089/8928

Krawczuk A. (2013), Struktury referujace z wyrazami pan/pani w polskojęzycznej prasie na Ukrainie: grzeczność czy niegrzeczność?, „Acta Universitatis Lodziensis. Kształcenie Polonistyczne Cudzoziemców" nr 20, s. 119-130. http://repozytorium.uni.lodz.pl:8080/xmlui/handle $/ 11089 / 4548$

Krucka B. (1996), Konfrontatywne nauczanie języka polskiego $w$ grupach Polonii ze Wscho$d u$, „Acta Universitatis Lodziensis. Kształcenie Polonistyczne Cudzoziemców” nr 7/8, s. 137-144. http://repozytorium.uni.lodz.pl:8080/xmlui/handle/11089/12866

Krucka B. (1997), Różnice w systemie składniowym języka polskiego i rosyjskiego, „Acta Universitatis Lodziensis. Kształcenie Polonistyczne Cudzoziemców" nr 9, s. 35-58. http://repozytorium.uni.lodz.pl:8080/xmlui/handle/11089/12728

Krucka B. (1998), Propozycja ćwiczeń przeciwdziałających interferencji języka rosyjskiego (na podstawie struktur składniowych oznaczajacych przyczynę), „Acta Universitatis Lodziensis. Kształcenie Polonistyczne Cudzoziemców" nr 10, s. 338-343. http://repozytorium.uni.lodz. pl:8080/xmlui/handle/11089/13012

Krucka B. (2002), Polsko-rosyjskie kontrasty w zakresie derywacji rzeczownikowej, „Acta Universitatis Lodziensis. Kształcenie Polonistyczne Cudzoziemców” nr 12, s. 43-68. http://repozytorium.uni.lodz.pl:8080/xmlui/handle/11089/12740

Krucka B. (2005), Błędy derywacyjne studentów rosyjskojęzycznych na tle polsko-rosyjskich kontrastów słowotwórczych, , ,Acta Universitatis Lodziensis. Kształcenie Polonistyczne Cudzoziemców" nr 14, s.57-94. http://repozytorium.uni.lodz.pl:8080/xmlui/handle/11089/12670

Kubacka K. (2013), Korekta nauczycielska a wypowiedź ustna studentów uczacych się języka polskiego jako obcego, „Acta Universitatis Lodziensis. Kształcenie Polonistyczne Cudzoziemców" nr 20, s. 385-396. http://repozytorium.uni.lodz.pl:8080/xmlui/handle/11089/4509

Kubacka K. (2014), Wprowadzanie nowych treści a strategie negocjacyjne lektora na lekcji języka polskiego jako obcego „Acta Universitatis Lodziensis. Kształcenie Polonistyczne Cudzoziemców” nr 21, s. 85-98. http://repozytorium.uni.lodz.pl:8080/xmlui/handle/11089/8587

Magajewska M (2005), Pozycja przymiotnika $w$ zdaniu polskim i włoskim - uwarunkowania syntaktyczne, , „Acta Universitatis Lodziensis. Kształcenie Polonistyczne Cudzoziemców” nr 14, s. 113-120. http://repozytorium.uni.lodz.pl:8080/xmlui/handle/11089/12644

Nikołajczuk K. (2013), Kompetencja rodzimych użytkowników polszczyzny oraz obcokrajowców (Ukraińców) w zakresie stosowania polskiej frazeologii temporalnej, „Acta Universitatis Lodziensis. Kształcenie Polonistyczne Cudzoziemców" nr 20, s. 83-92. http://repozytorium.uni. lodz.pl:8080/xmlui/handle/11089/4521

Norrish J. (1983), Language Learners and their Errors, Macmillan Publishers Ltd., London.

Nowikow W. (1988), O formie i znaczeniu condicionalis $w$ językach iberoromańskich $i$ stowiańskich, „Acta Universitatis Lodziensis. Kształcenie Polonistyczne Cudzoziemców” nr 1, s. 79-84. http://repozytorium.uni.lodz.pl:8080/xmlui/handle/11089/12594 
Nowikow W. (1988), Pojęcie funkcji w kontrastywnych badaniach gramatycznych i glottodydaktyce, „Acta Universitatis Lodziensis. Kształcenie Polonistyczne Cudzoziemców” nr 1, s. 71-78. http://hdl.handle.net/11089/12593

Orhorilko O. (2011), Osobliwości składni rzadu w tekstach ukraińskich studentów polonistów, „Acta Universitatis Lodziensis. Kształcenie Polonistyczne Cudzoziemców” nr 18, s. 279-284. http://repozytorium.uni.lodz.pl:8080/xmlui/handle/11089/9372

Pančiková M. (1996), Interferencia - dôležity problém vo výučbe slovanských jazykov, „Acta Universitatis Lodziensis. Kształcenie Polonistyczne Cudzoziemców" nr 7/8, s. 129-136. http://repozytorium.uni.lodz.pl:8080/xmlui/handle/11089/12864

Sajenczuk E. (1987), Próba przedstawienia błędów popetnianych najczęściej przez studentów wietnamskich w czasie uczenia sie języka polskiego w Polsce. „Acta Universitatis Lodzinsis. Kształcenie Polonistyczne Cudzoziemców” (nr 0 - próbny), s. 90-99 (brak adresu elektronicznego).

Seretny A. (2014), Rola efektu zwrotnego w dyskursie interakcyjnym, „Acta Universitatis Lodziensis. Kształcenie Polonistyczne Cudzoziemców” nr 21, s. 37-50. http://repozytorium.uni.lodz. pl:8080/xmlui/handle/11089/8566

Sikorska T. (1996), System fonologiczny języka polskiego w porównaniu z serbskim, „Acta Universitatis Lodziensis. Kształcenie Polonistyczne Cudzoziemców” nr 7/8, s. 145-152. http://repozytorium.uni.lodz.pl:8080/xmlui/handle/11089/12867

Sikorski L. (1987), Z problemów leksykalno-składniowych w grupie z językiem niemieckim, „Acta Universitatis Lodziensis. Kształcenie Polonistyczne Cudzoziemców” (nr 0 - próbny), s. 100-110 (brak adresu elektronicznego).

Sitkowska K. (2013), Polszczyzna z zagranicy w programach telewizyjnych (kompetencja komunikacyjna celebrytów), „Acta Universitatis Lodziensis. Kształcenie Polonistyczne Cudzoziemców” nr 20, s. 209-218. http://repozytorium.uni.lodz.pl:8080/xmlui/handle/11089/4479

Skura M. (2013), Btędy wynikajace z interferencji kulturowej popetniane przez Niemców uczacych się języka polskiego jako obcego, ,Acta Universitatis Lodziensis. Kształcenie Polonistyczne Cudzoziemców” nr 20, s. 149-158. http://dspace.uni.lodz.pl:8080/xmlui/handle/11089/4511

Stasieczek-Górna M. (2011), Błędy szyku zdania popetniane przez cudzoziemców uczacych się języka polskiego, „Acta Universitatis Lodziensis. Kształcenie Polonistyczne Cudzoziemców” nr 18, s. 295-302. http://repozytorium.uni.lodz.pl:8080/xmlui/handle/11089/9243

Turton N D, Heaton J B (1996), Longman Dictionary of Common Errors. New Edition, Longman Group, GB.

Witkowska-Gutkowska M. (2008), O tekstach prasowych autorstwa osób dwujęzycznych, „Acta Universitatis Lodziensis. Kształcenie Polonistyczne Cudzoziemców” nr 16, s. 153-158. http://repozytorium.uni.lodz.pl:8080/xmlui/handle/11089/12300

Witkowska-Gutkowska M. (2011), O tekstach prasowych osób dwujęzycznych. Stownictwo i frazematyka, „Acta Universitatis Lodziensis. Kształcenie Polonistyczne Cudzoziemców” nr 18, s. 19-24. http://repozytorium.uni.lodz.pl:8080/xmlui/handle/11089/9255

Witkowska-Gutkowska M. (2013),Wpływ języka czeskiego na polszczyznę publikacji w zaolziańskim ,, Głosie Ludu”, „Acta Universitatis Lodziensis. Kształcenie Polonistyczne Cudzoziemców" nr 20, s. 177-186. http://repozytorium.uni.lodz.pl:8080/xmlui/handle/11089/4546

Wtorkowska M. (2011), Problemy fonetyczne Stoweńców uczących sie języka polskiego „Acta Universitatis Lodziensis. Kształcenie Polonistyczne Cudzoziemców” nr 18, s. 243-252. http:// repozytorium.uni.lodz.pl:8080/xmlui/handle/11089/9377

Zarzycka G. (2013), Dyskurs glottodydaktyczny na łamach „Kształcenia Polonistycznego Cudzoziemców” w latach 1987-2013, „Acta Universitatis Lodziensis. Kształcenie Polonistyczne Cudzoziemców” nr 20, s. 11-22. http://repozytorium.uni.lodz.pl:8080/xmlui/handle/11089/4437 


\section{Grażyna Zarzycka}

Keywords: lapsology, teaching Polish as a foreign language, lapsology of Polish as a foreign language, glottodidactic error

Summary. The author postulates to use the term lapsology of Polish as a foreign language (LPFL) to refer to the research on any type of errors which appear in the process of learning and teaching Polish as a foreign language. In her opinion, this discipline examines 'glottodidactic errors' which can be made not only by the learners of Polish as a foreign language but also by the teachers, at every stage of the educational process. In the first part of the article, the author presents the history of LPFL. The presentation is based on the content analysis of articles published between 1987-2014 in 'Acta Universitatis Lodziensis. Kształcenie Polonistyczne Cudzoziemców' ['Studies in the Teaching Polish to Foreigners']. In the second part of the article, the author discusses the content of the current 22nd volume of this periodical, entitled Glottodidactic Error. In the discussion, she focuses especially on the newest trends in LPFL. 